\title{
Commentaries
}

\section{Europe versus America?}

\section{JONATHAN MORRIS}

School of Humanities, University of Hertfordshire, Hatfield, AL10 9AB, UK. E-mail: j.2.morris@herts.ac.uk

The simple shibboleths of sports history - that the British showed the Europeans how to play sport, while the Americans taught them how to turn it into a commodity - can no longer be sustained. As Tomlinson and Young rightly maintain, it is time to work towards a new history of European sport that can incorporate the richness and diversity of experiences to which the contributions in this focus section point. Such an approach should recognise that not only has the accretion of research into sports history undermined the stereotype of Europe as a passive recipient of sporting innovations, so too it will require a rethinking of our understanding of the roles of Britain and the United States of America.

The more sophisticated account of the evolution of Europe's 'sport space' that is presented in these pages is reflective of the diffusion and maturation of a still relatively young sub-field. While the extent to which sports history won earlier acceptance in the Anglo-American academy than on the continent is debatable, it is certain that the real spur to more integrated interpretations of European sport will be the growth of opportunities for transnational exchanges between scholars. ${ }^{1}$ This is a process to which Tomlinson and Young (along with Richard Holt) have already made a considerable contribution through their promotion of a pan-European research network. In this themed issue, for example, we have specific contributions on Italy and Spain, whereas the editors of the Routledge Companion to Sports History, an otherwise definitive attempt to capture the 'state of the art' published at the end of 2009, were still invoking a supposed lack of local scholarship, along with the old perennial of linguistic barriers, to excuse the absence of any chapters dealing with the southern European nations. ${ }^{2}$

Given the foregrounding of three contributions on the 'Latin' countries within this collection, it is surprising that Tomlinson and Young shy away from producing a fifth 'Mediterranean' ideal-type to sit alongside the others they outline 
in their Introduction. Of course they are right to point to some marked differences between the countries, particularly if one attempts to stretch the category to include France for which Dietschy makes a plausible case for distinctiveness. However, McFarland's exposition of how sport became central to the project of the 'Europeanisation' of Spain, finds many echoes in Italy, which was likewise sensitive about its position on the periphery of the West European core, and keen to use sport to project itself into the mainstream. What seems distinctively Mediterranean to this approach is the emphasis on sports politics as a path through which to pursue international prestige. This was true as much under the successor democratic regimes as during the Fascist dictatorships, culminating in the long and parallel terms in office of Juan Antonio Samaranch (President of the International Olympic Committee, 1980-2001) and Primo Nebiolo (President of the International Amateur Athletics Association, 1981-1999). Here, there are strong parallels with France's prominence within so many of the international sports federations founded in the interwar era, at a time when her 'hard' diplomatic power was waning as a result of the rise of Germany and the United States.

France, Italy and Spain are also home to the three main multi-stage European cycling 'tours'. In these, the intention of assisting citizens with 'imagining the nation', including those regions whose incorporation into the collective posed as many problems for politicians as they did challenges to the cyclists, can clearly be discerned. In Italy and Spain, the institution of the 'tours' again formed part of the 'Europeanisation' process, predicated on demonstrating the ability to organise a major 'modern' sports event within a 'united nation', while the original Tour de France was both born of, and a response to, the internal divisions that arose out of the Dreyfus affair.

If the cultural projects embedded in the 'tours' have been well-recognised, more emphasis needs to be given to the entrepreneurial innovation under-laying them. This consisted of creating commercial products that could be consumed not just by the spectators, but by the reading public as well. ${ }^{3}$ Henri Desgranges, the former racer, writer and director of L'Auto established the Tour de France as a way to build up the fortunes of his paper in 1903, while in 1909 Emilio Costamagna, editor of La Gazetta dello Sport created the Giro d'Italia in direct imitation - in effect, another early form of 'Europeanisation'. Not just the sport, but the sportsmen were turned into symbolic commodities to be consumed through the press; and, as Martin shows for Italy, as props for political communications in the immediate post-war era.

European sporting entrepreneurs took their inspiration from older forms of entertainment within their own nations, rather than the new forms of professional sport evolving in America. ${ }^{4}$ One of the first men to invest in velodromes in France was Clovis Clerc, the then director of the Folies Bergères, while bullfighting provided the first Spanish promoters with a formula for the commodification of 
spectator sports such as football. Nor should one overlook the fact that in Britain too, cycle racing was one of the first sports to turn itself into a spectator product capable of supporting professional riders, quickly graduating from displays staged within circus or music-hall style presentations, to races staged in purpose-built velodromes, such as that erected in Molineux Gardens, Wolverhampton. The velocipede 'craze' that erupted in England in 1869, the year that the machines arrived from France, was such that already in the first half of the 1870 s crowds of 10-18,000 paid to watch events such as 'World Championships', featuring British, French and Belgian riders, conducted under the 'Wolverhampton' rules that governed professional contests. ${ }^{5}$

Cycling was a continental sport that travelled to Britain rather than vice versa, but its rapid acceptance on the other side of the channel is more suggestive of similarities rather than differences in the European 'sporting space' of the time. The first importer of velocipedes was Charles Spencer, an ex-gymnastic champion and proprietor of a popular gymnasium in the City of London, whose success suggested the British too were once enthusiasts for the kind of gymnastic activities that have often been portrayed as exclusive to the continent. By the 1870s, Spencer had combined running the gymnasium with the manufacture and sale of gymnastic and weight-lifting apparatus, velocipedes and a variety of fencing, football, cricket, hockey and croquet equipment, as well as publishing two books, The Modern Gymnast and The Bicycle, Its Use and Action, that effectively served as guides to the sports. ${ }^{6}$

Spencer resembles no-one so much as the American entrepreneur Albert Spalding, the baseball player who subsequently founded a sporting empire that dominated the sports market in the United States. Stephen Hardy has suggested that the sports commodity is composed of three products - the 'game form' itself, services ancillary to this, and the equipment required to play - arguing that Spalding was the first to trade in all three simultaneously by virtue of publishing handbooks to baseball that effectively codified the rules (and hence the game form) of the sport. ${ }^{7}$ If so, the same clearly applies to Spencer, while the innovative entrepreneurship demonstrated by continental promoters such as Desgranges throws further doubt on the characterisation of American sports simply laying down a business model that others belatedly followed. Attempts to define a European model of sports culture against an American one fall down not only because the Europeans were more commercially minded than their political representatives are prepared to admit, but equally because America's sporting values are more complex than many commentators care to countenance.

The notion that sport in America has no roots in associational activity is easily refuted by the reproduction of gymnastic societies such as the German Turner, Polish Falcons and Pan-Slavic Sokol amongst immigrants from these nations to the United States. By 1894, there were 314 societies affiliated to the Nordamerikanischer Turnerbund, with a combined membership of c. 40,000 plus a 
further 25,000 children and 3000 women 'auxiliary' members participating in a range of activities that promulgated Germanic culture within a 'freethinking' environment. ${ }^{8}$ The ethnic identity of these associations, however, meant that they were unable to furnish one of the key 'auxiliary services' that Hardy saw as having been commodified within the membership of sports clubs, namely the conferment of social status or simple integration into the broader community.

Such a role could only be played by distinctively American sports organised around institutions that were at least symbolically open to all designated members of 'American' society. This accounts for the much greater adoption of high school and college teams as focal points for local identification in the United States, and of the key role of educational organisations in defining and transmitting the 'sports form', while a significant portion of adult recreation, particularly exposure to the 'American sports', was organised through the workplace.' This separation of elite sport from a mass base is epitomised by the way that professional teams in the three hegemonic sports - baseball, American football and basketball - do not operate their own training academies, but 'draft' in new recruits from the college teams.

Conversely, as in Europe, the amateur and professional divide was also used to demarcate class borders and confer social status. The elite New York Athletic Club and its offshoot, the Amateur Athletic Union, remained responsible for the organisation of the United States Olympic Team until 1978, with administrators such as Avery Brundage (President of the IOC, 1952-72) demonstrating as limited a commitment to the ideal of democracy as Coubertin did to universalism. Black athletes were unable to compete at the NYAC until the 1960s, while sports such as tennis and golf were conducted largely within the milieu of upper class country clubs whose attractions were more about access to status than sporting facilities.

It was, though, the American sports that best defined the boundaries of 'the nation'. The exclusion of African-Americans from the 'imagined community' was encapsulated by their absence from the highest levels of professional baseball prior to the breakthrough of Jackie Robinson in 1947. For that matter, although the United States has participated in every qualification competition for the World Cup since its inception, 'soccer' has featured little in the American sports consciousness until recently, because the players have largely been drawn from immigrant communities who had yet to be welcomed into mainstream America (such as Joe Gaetjens, the Haitian student whose goal famously knocked England out of the finals in 1950).

These social restrictions subvert the sense of the American sporting space as simply another sphere subjugated to the business-driven imperatives of a mass consumption society. Indeed, in contrast to similar mass entertainment industries, such as film and music, there has been relatively little 'Americanisation' of the global market. Even in the sporting goods sector, American success is largely predicated on influence over urban fashions rather than sporting cultures. 
The irony here is that the promotion of American sports as an aid to integrating the nation has deprived the USA of the opportunity of using international sport as a focus for national identification. ${ }^{10}$ This makes a sharp contrast with Europe where international conflict and competition have always played a major role in shaping national consciousness, and not just on the sports field.

The lack of an international dimension is one of a number of 'exceptional' features of the American sports space that European sports fans find difficult to accept, leading to an attack on the reduction of sport to an entertainment business, composed of franchises with no community linkages, leagues that lack promotion and relegation, and restrictions on the payment and movement of players. ${ }^{11}$ In short, why can't American football, be more like European football? It is somewhat ironic, then, that as UEFA seeks to prevent its flagship Champions League tournament from becoming the preserve of a few highly capitalised clubs buying their way to success, it is increasingly looking to American-style controls such as salary caps, player 'quotas' and regional allocations to avoid supposed sporting values being overwhelmed by commercial ones.

Not only, then, do we need to think more about reconceptualising the evolution of European sports space, we also need to consider the impact of this upon our readings of Britain and America. By following Tomlinson and Young's injunctions to avoid the lure of 'presentism', accept the complexity of overlapping (within both space and time) patterns and connections, and seek to explain variety rather than simplify it, we can incorporate into our analysis an appreciation of the innovative nature of European sports entrepreneurship, recognise the United Kingdom's experience as both a recipient (cycling) and re-exporter (speedway) of sporting forms, ${ }^{12}$ as well as acknowledging the extent of amateur and associational-based sporting activities within the United States. A simple opposition of 'Europe' (following in Britain's footsteps) against 'America' can be left to the promoters of the Ryder Cup.

\section{References and Notes}

1. In Italy, for example, serious works on the history of sport were already being published in the 1980s, such as S. Pivato's (1986) Sia lodato Bartoli. Ideologia, cultura e miti dello sporto catolico (Rome: Ed. Lavoro, Rome).

2. S. W. Pope and J. Nauright (2009) Introduction. In: S. W. Pope and J. Nauright (eds) Routledge Companion to Sports History (New York: Routledge), pp. 21-29.

3. C. S. Thompson (2006) The Tour de France: A Cultural History (Berkeley: University of California Press).

4. D. Porter (2009) Entrepreneurship. In: S. W. Pope and J. Nauright (eds) Routledge Companion to Sports History (New York: Routledge), pp. 197-215, provides a valuable discussion of the connections between sports and business on both continents. 
5. See A. Ritchie (1999) The origins of bicycle racing in England: technology, entertainment, sponsorship and advertising in the early history of sport. Journal of Sport History, 23(2), 489-520.

6. A. Ritchie (1999) The origins of bicycle racing in England: technology, entertainment, sponsorship and advertising in the early history of sport. Journal of Sport History, 23(2), 493-494.

7. S. Hardy (1986) Entrepreneurs, organizations, and the sport marketplace: subjects in search of historians. Journal of Sport History, 13(1), 14-33.

8. G. R. Gems and G. Pfister (2009) Understanding American Sports (Oxford and New York: Routledge), pp. 70-71, 82.

9. G. Pfister (2009) Box 2.8: On the role of sports clubs. In: G. R. Gems and G. Pfister (2009) Understanding American Sports (Oxford and New York: Routledge), p. 55.

10. A. Bairner (2001) Sport, Nationalism and Globalization (New York: SUNY Press), pp. 13-14, 91-113.

11. For a debate between fans of American and European sports over these issues see http://crookedtimber.org/2009/05/27/uk-vs-us-sports-leaguesa-little-industrial-organisation-analysis (accessed 5 November 2010).

12. J. Williams (1999) 'A wild orgy of speed': responses to speedway in Britain before the Second World War. Sport in History, 19(1), 1-15.

\section{About the Author}

Jonathan Morris is Research Professor of Modern European History at the University of Hertfordshire. His main research interests lie in the history of consumption, retailing and self-employment in the twentieth century, alongside a general interest in the history of Italy from unification to the present day. His publications include the monograph The Political Economy of Shopkeeping in Milan 1886-1922 (1993), edited volumes on The New History of the Italian South (1997), American Exceptionalism? US Working Class Formation in International Comparison (1997), and journal themed issues on The Petite Bourgeoisie in Europe 1914-45 (1996) and Made in Italy. Consumi e identitá collettive nel second dopoguerra (2006). He edited the journal Contemporary European History from 1998 to 2007, and directed the research project 'The Cappuccino Conquests: A Transnational History of Italian Coffee' from 2004-2007. He is currently completing a global history of coffee. 